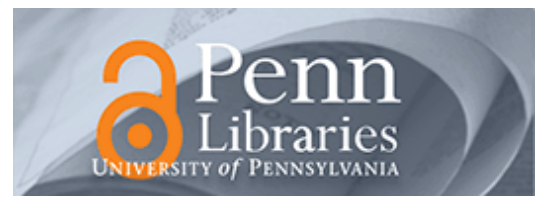

University of Pennsylvania ScholarlyCommons

\title{
A Comparison of Five Introductory Textbooks in Global Health
}

\author{
Neal Nathanson \\ University of Pennsylvania, nathansn@upenn.edu \\ Thomas Hall \\ University of California - San Francisco
}

Follow this and additional works at: https://repository.upenn.edu/global_health

Part of the Medicine and Health Sciences Commons

Nathanson, Neal and Hall, Thomas, "A Comparison of Five Introductory Textbooks in Global Health" (2011). Global Health Programs. 4.

https://repository.upenn.edu/global_health/4

-With the collaboration of 37 participants from the Global Health Education Consortium Suggested Citation:

Nathanson, N., Hall, T., \& the collaboration of 37 participants. (2011). A comparison of five introductory textbooks in global health. Global Public Health, 6(2), 210-219. doi: http://dx.doi.org/10.1080/17441692.2010.545360

This is an electronic version of an article published in Global Public Health, 6(2). Global Public Health is available online at: http://www.informaworld.com/

This paper is posted at ScholarlyCommons. https://repository.upenn.edu/global_health/4

For more information, please contact repository@pobox.upenn.edu. 


\title{
A Comparison of Five Introductory Textbooks in Global Health
}

\author{
Abstract \\ A Review of: \\ Essentials of global health, by R. Skolnik, Sudbury, Jones and Bartlett Publishers, 2008, 322 pp., including \\ index and supplementary materials, US\$57 (paperback), ISBN 13: 978-0-7637-3421-3; ISBN 10: \\ 0-7637-3421-7 \\ Understanding global health, edited by W.H. Markle, M. Fisher and R. Smego, Columbus, McGraw Hill, \\ 2007, 361 pp., including index and supplemental materials, US\$35 (paperback), ISBN 13: \\ 978-0-07-148784-9; ISBN 10: 0-07-148784-0 \\ Global health, an introductory textbook, by A. Lindstrand, S. Bergstrom, H. Rosling, B. Rubenson, B. \\ Stenson and T. Tylleskar, Denmark, Studentlitteratur, 2006, 310 pp., including index and supplemental \\ materials, US\$35 (paperback), ISBN 978-91-44- 02198-0 \\ An introduction to international health, by M. Seear, Toronto, Canadian Scholars Press, 2007, 352 pp., \\ including index and supplemental materials, US\$49 (paperback), ISBN 978-1-55130-327-7 \\ Introduction to global health, by K.H. Jacobsen, Sudbury, Jones and Bartlett Publishers, 2008, 366 pp., \\ including index and supplemental materials, US\$43 (paperback), ISBN 13: 978-0-7637-5159-3; ISBN 10: \\ 0-7637-5159-6 \\ Disciplines \\ Medicine and Health Sciences \\ Comments \\ -With the collaboration of 37 participants from the Global Health Education Consortium \\ Suggested Citation: \\ Nathanson, N., Hall, T., \& the collaboration of 37 participants. (2011). A comparison of five introductory \\ textbooks in global health. Global Public Health, 6(2), 210-219. doi: http://dx.doi.org/10.1080/ \\ 17441692.2010 .545360
}

This is an electronic version of an article published in Global Public Health, 6(2). Global Public Health is available online at: http://www.informaworld.com/ 


\section{BOOK REVIEW}

\section{A comparison of five introductory textbooks in global health}

Neal Nathanson ${ }^{\mathrm{a} *}$ and Thomas Hall ${ }^{\mathrm{b} *}$ with the collaboration of 37 participants $^{\mathrm{c}}$

${ }^{a}$ School of Medicine, University of Pennsylvania, Philadelphia, PA, USA; ${ }^{b}$ Department of Epidemiology \& Biostatistics, School of Medicine, University of California, San Francisco, CA, USA; ${ }^{c}$ Global Health Education Consortium

Essentials of global health, by R. Skolnik, Sudbury, Jones and Bartlett Publishers, 2008, 322 pp., including index and supplementary materials, US\$57 (paperback), ISBN 13: 978-0-7637-3421-3; ISBN 10: 0-7637-3421-7

Understanding global health, edited by W.H. Markle, M. Fisher and R. Smego, Columbus, McGraw Hill, 2007, 361 pp., including index and supplemental materials, US\$35 (paperback), ISBN 13: 978-0-07-148784-9; ISBN 10: 0-07-148784-0

Global health, an introductory textbook, by A. Lindstrand, S. Bergstrom, H. Rosling, B. Rubenson, B. Stenson and T. Tylleskar, Denmark, Studentlitteratur, 2006, 310 pp., including index and supplemental materials, US\$35 (paperback), ISBN 978-91-4402198-0

An introduction to international health, by M. Seear, Toronto, Canadian Scholars Press, 2007, 352 pp., including index and supplemental materials, US\$49 (paperback), ISBN 978-1-55130-327-7

Introduction to global health, by K.H. Jacobsen, Sudbury, Jones and Bartlett Publishers, 2008, 366 pp., including index and supplemental materials, US\$43 (paperback), ISBN 13: 978-0-7637-5159-3; ISBN 10: 0-7637-5159-6

\section{Introduction}

At academic institutions in the USA, there has been a great burgeoning of interest in global health, initiated by undergraduate, graduate and professional students. In response, many universities have launched courses, programmes and degrees that present information, teach methods, and build relevant skills. Concomitantly, there has been a rapid increase of publications in global health including a number of new textbooks.

The Global Health Education Consortium (GHEC) was created to foster education in this discipline. In pursuit of its mission, GHEC has an Education Committee, currently chaired by Timothy Brewer, with more than 20 volunteer

*Corresponding authors. Email: nathansn@upenn.edu; thall@epi.ucsf.edu 
members. The Education Committee undertakes a variety of projects that are designed to facilitate various aspects of the GHEC mission. In this report, we present the results of one such project, an evaluation of introductory textbooks in global health. Among texts in global health, five introductory books were selected for comparison: Skolnik, R., Essentials of Global Health; Markle, W.H. et al., eds., Understanding Global Health; Lindstrand, A. et al., Global Health, an Introductory Textbook; Seear, M., An Introduction to International Health; and Jacobsen, K.H., Introduction to Global Health.

The purpose of this exercise was to provide faculty who are developing courses in global health with a comparative evaluation of introductory textbooks in this field. In particular we strove to characterise the 'flavour' of each book, its strengths and weaknesses, and its fit for different student audiences. Our approach was modelled on the evaluations that are published by the magazine Consumer Reports, in which similar products are compared across a variety of parameters, using a rating scale for each parameter. In view of the wide range of knowledge required, we recruited a large number of volunteer evaluators, using experts, faculty and student participants.

\section{Methods}

The evaluation was developed in a stepwise fashion. (A) We first identified recently published textbooks in global health and sorted them into a group for evaluation and a group that was excluded. We limited this project to five introductory textbooks because they were likely to be the most widely used and were roughly comparable (see Table 1). Excluded were a variety of large textbooks and books that focused on specific areas of global health. ${ }^{1}$ These judgements were supported by the GHEC Education Committee. (B) We reviewed the contents of the five books and sorted the chapters into 12 distinct subject categories (see Table 2). We constructed a set of six parameters for evaluation of each of the subject categories: quality of information, quality of presentation, quality of illustrations, quality of supporting materials, appropriate for undergraduate students and appropriate for graduate students. Each parameter was rated on a scale: $5=$ outstanding, $4=$ excellent, $3=$ good, $2=$ fair, and 1 = poor. (C) We then sought volunteers to review individual subject categories. The goal was to identify at least three reviewers, an 'expert', a faculty member, and a student for each category. We solicited unpaid volunteers, and gave them the opportunity to select a subject category that they felt qualified to review; volunteers identified themselves as experts, faculty, or students. For this purpose, we emailed a list of more than 200 names provided by GHEC. A total of 41 people volunteered, most of whom reviewed only a single subject category; of these 41, 36 reviewers completed 41 individual reviews (see Acknowledgements). Nine subject categories received three or four reviews and three categories received only two reviews. (D) We distributed copies of the five books by mail, and respondents entered their evaluations in a Surveymonkey (C) questionnaire. In addition to rating parameters, respondents could add verbal comments; a total of about 50 pages of comments were received. (E) Four 'experts' were recruited to provide an overall comparison of the books. Their responses played a major role in the qualitative component of the report. $^{2}$ 
Table 1. Introductory textbooks of global health: books that were reviewed.

\begin{tabular}{|c|c|c|c|c|}
\hline Books & Publisher year & $\begin{array}{l}\text { Retail price } \\
\text { (US dollars) }\end{array}$ & Number of authors & $\begin{array}{c}\text { Pages } \\
\text { (Text Index Supplementary) }\end{array}$ \\
\hline Essentials of Global Health & Jones and Bartlett & $\$ 57$ & 1 & 296 \\
\hline Skolnik R & $\begin{array}{l}\text { Publishers } \\
2008\end{array}$ & & & $\begin{array}{r}22 \\
4\end{array}$ \\
\hline Understanding Global Health & McGraw Hill & $\$ 35$ & 3 editors & 341 \\
\hline Markle W.H., et al. & 2007 & & 33 authors & $\begin{array}{r}20 \\
0\end{array}$ \\
\hline $\begin{array}{l}\text { Global Health, An Introductory Textbook } \\
\text { Lindstrand A., et al. }\end{array}$ & $\begin{array}{l}\text { Studentlitteratur } \\
2006\end{array}$ & $\$ 35$ & 6 & $\begin{array}{r}310 \\
6 \\
9\end{array}$ \\
\hline $\begin{array}{l}\text { An Introduction to International Health } \\
\text { Seear M. }\end{array}$ & $\begin{array}{l}\text { Canadian Scholars Press } \\
2007\end{array}$ & $\$ 49$ & 1 & $\begin{array}{r}346 \\
16 \\
0\end{array}$ \\
\hline $\begin{array}{l}\text { Introduction to Global Health } \\
\text { Jacobsen K.H. }\end{array}$ & $\begin{array}{l}\text { Jones and Bartlett } \\
\text { Publishers } \\
2008\end{array}$ & $\$ 43$ & 1 & $\begin{array}{r}319 \\
24 \\
23\end{array}$ \\
\hline
\end{tabular}


Table 2. Rating of subject categories covered by each book.

\begin{tabular}{|c|c|c|c|c|c|c|c|c|c|c|c|c|c|}
\hline \multirow[b]{2}{*}{ Books } & \multicolumn{13}{|c|}{ Category } \\
\hline & Introduction & $\begin{array}{l}\text { Measures } \\
\text { of disease }\end{array}$ & $\begin{array}{c}\text { Determinants } \\
\text { of health }\end{array}$ & $\begin{array}{c}\text { Communicable } \\
\text { diseases }\end{array}$ & $\begin{array}{c}\text { Non- } \\
\text { communicable } \\
\text { iseases }\end{array}$ & $\begin{array}{l}\text { Environmental } \\
\text { health }\end{array}$ & Nutrition & $\begin{array}{l}\text { Maternal } \\
\text { child } \\
\text { health }\end{array}$ & $\begin{array}{c}\text { Humanitarian } \\
\text { disasters }\end{array}$ & $\begin{array}{l}\text { Health } \\
\text { systems }\end{array}$ & $\begin{array}{l}\text { Global } \\
\text { aid }\end{array}$ & Ethics & $\begin{array}{c}\text { Total } \\
\text { subjects } \\
\text { covered } \\
\text { (of } 12 \text { ) }\end{array}$ \\
\hline Skolnik & 3.3 & 4.0 & 3.4 & 3.1 & 4.3 & 3.5 & 3.8 & 3.9 & 3.0 & 4.3 & 4.0 & 3.4 & 12 \\
\hline Markle & 3.5 & 4.8 & 2.5 & 3.2 & 4.1 & 2.5 & 4.3 & 3.7 & 4.1 & 3.6 & 3.9 & 3.5 & 11 \\
\hline Lindstrand & & 3.0 & 3.2 & 3.5 & 3.2 & & 3.5 & 2.7 & & 3.3 & 2.4 & & 8 \\
\hline Seear & 3.6 & 2.8 & 2.9 & & & & 3.2 & & 3.1 & 2.6 & 3.8 & 2.1 & 8 \\
\hline Jacobson & 2.3 & 2.8 & 3.2 & 2.0 & & 3.2 & 2.3 & 2.6 & & & 3.0 & & 8 \\
\hline
\end{tabular}

Note: Rating scale: 5 , outstanding; 4, excellent; 3 , good; 2 , fair; 1 , poor. 
We used analysis of variance (ANOVA) with post-hoc Tukey multiple comparison tests to determine whether there were significant pairwise differences between book ratings. We used SAS V9.2 (SAS Institute, Inc., Cary, NC) for the analysis.

As described above, we took two approaches to evaluation of the five books, qualitative comments to characterise each book and describe its strengths and weaknesses, and a semi-quantitative evaluation to rate individual subject categories. Both of these data-sets are presented in the following section.

\section{Findings}

An overview of the books is shown in Table 1 . The books were all about the same length (300-350 pages), were published about the same date (2006-2008), and ranged in retail price from US\$35 to US\$57. Three books were single author products, one was written by a team of six authors, and one was a multi-authored book overseen by three editors. For convenience, we will refer to each book by the name of its first author or editor.

\section{Qualitative comments about each book}

We asked four well-qualified 'experts' to do an overall review of the five books, both to provide a 'flavour' of each book and to comment and compare them as introductory texts in global health. The comments of reviewer 1 are representative and reproduced below, unchanged except for minimal editing.

\section{Skolnik}

Reviewer 1. This is a well-written, authoritative overview of global health issues. While it may be the most expensive of the books reviewed it also seemed good value for money in terms of the range of its coverage and the accessibility of its materials. It is well structured, building the reader's understanding step by step, with clear learning objectives, conclusions and study questions for each chapter. It illustrates each issue with vignettes that help the reader imagine what it is like to experience health conditions in rich and poor countries, well-chosen statistics and figures and case studies usually at system level. It was the most wide-ranging of the books reviewed, covering all the major issues affecting global health. From a personal perspective I would have liked to see more emphasis on globalisation and global governance, but aside from this it was a comprehensive introduction to the topic. It would certainly be useful for undergraduates as well as a good introductory book for health professional students.

\section{Markle}

Reviewer 1. This is an impressive reference book, full of the sort of information and detail needed to cover nearly all fields of global health. The figures and examples are well chosen and clear. It is more suitable for a health professional with some understanding of the field than an undergraduate. Because different authors contribute each chapter there is less continuity and building of knowledge. The smaller page and print sizes may present a problem for some and an advantage for 
others. Within each chapter, there are clear learning objectives, examples and study questions. It covers all the main fields well, with relatively less emphasis on globalisation, global governance and health systems and more emphasis on specific diseases. It covers displacement and conflict better than most of the other books reviewed.

\title{
Lindstrand
}

Reviewer 1. This is a book of great ambition, written by a team of Swedish academics with broad vision and strong views. It swoops from a history of human development, through the main causes of the burden of global disease to the development of health systems and global cooperation. Some chapters verge on a polemic while others are more of an extended glossary. While I found it lively and enjoyable to read in places, this was a personal view. It must be said it is not well structured as a text for students or a reference source for health professionals. It does not clarify its learning objectives or explain its conclusions, its examples are intermittent and while it leaves the reader with suggestions for further study one is not sure why these references are suggested. Coverage of the field is frankly patchy with perhaps too much emphasis upon an analysis of the broad sweep of history and the burden of disease and too little discussion of what to do about it in the twenty-first century. It is enjoyable to read in conjunction with Hans Rosling's 'gapminder' images and these are useful teaching aids, but overall the book does not meet the need for a basic text on global health.

\begin{abstract}
Seear
Reviewer 1. This is a book about international health, focused on health in poor countries and the impact, or lack of it, of overseas aid from rich countries rather than global health issues affecting health across boundaries that must be addressed through international cooperation. Though not covering the full range of global health issues it still raises important questions. In fact these questions provide a useful structure for the book and each chapter sets clear learning objectives. As an overview of the subject it provides a reasonable introduction for students. It attempts to enliven the subject with insightful statistics, some illustrations and some quotations. Personally I found these rather distracting and irritating but others may enjoy them. What I found lacking was any more ambitious solutions and while the author makes it clear that aid is not working he does not seem to suggest an approach that would offer greater hope. It seemed a little too basic for health care professionals while not providing enough basic coverage for an introduction to the subject.
\end{abstract}

\section{Jacobsen}

Reviewer 1. This is a well set out basic introductory text, though most of its focus is on international health. It introduces the issues and terms and builds a description of the current challenges and international health systems. While the overall organisation of the book is topic driven, each chapter has 'key points' for the reader. What is 
less clear is what conclusions should be drawn from each chapter or from the book as a whole. The reader is left with some useful information but no summary or questions to help them process this to decide what should be done about it. The book is well indexed and has several appendices largely drawn from UN sources but I could not help wondering why the reader could not simply look these documents up. I welcome the discussion of the application of the Articles of WHO and the Universal Declaration of Human Rights but I did not need to have them as appendices.

\section{Comments by other reviewers}

The comments of the other three expert reviewers were for the most part consistent with those of reviewer 1 . They added a few additional points noted here.

Skolnik. This book is structured to follow the publication Disease Control Priorities In Developing Countries ${ }^{3}$ with emphasis on epidemiological data and cost-effectiveness of interventions.

Markle. This book has excellent coverage of global health and more in-depth exposition than some of the other books.

Lindstrand. While some reviewers liked certain aspects of this book, all agreed that it was not well designed as an introductory text, partly because it reflects the particular views of the authors.

Seear. This book was considered to be somewhat unbalanced in the strong emphasis given to development and aid, with relatively cursory treatment of some other topics.

Jacobsen. This book was considered to be very basic and, while well written, to give minimal coverage to a number of important topics.

The individual reviewers who rated specific subject categories contributed a large number of comments. Since these comments were optional they were rather patchy, and most of them were explanations of (and reflected in) their numerical ratings. Therefore, no attempt has been made to summarise them further in this report.

\section{Semi-quantitative comparisons}

\section{Comparison by six parameters}

Each book was rated on six parameters (see Table 3): quality of information, quality of presentation, quality of illustrations, quality of supplemental materials, appropriate for undergraduates and appropriate for graduate and professional students. Four parameters (information, presentation, illustrations, and supplemental materials) were grouped to form a composite measure of quality. As Table 3 indicates, two of the books (Skolnik and Markle) received the best ratings (3.77 and 3.68), while the other three books were somewhat lower (3.02-2.64). Furthermore, each book received quite consistent ratings across the four quality parameters.

ANOVA showed that there were differences in the composite measure of quality in Table $3(p<0.0001)$. The Tukey multiple comparison test results 
Table 3. Ratings of books by various parameters.

\begin{tabular}{|c|c|c|c|c|c|c|c|c|}
\hline \multirow[b]{2}{*}{ Books } & \multicolumn{8}{|c|}{ Parameter } \\
\hline & $\begin{array}{c}\text { Quality } \\
\text { (Four measures) } \\
N=111-146\end{array}$ & $\begin{array}{l}\text { Information } \\
N=23-35\end{array}$ & $\begin{array}{c}\text { Presentation } \\
N=26-37\end{array}$ & $\begin{array}{l}\text { Illustrations } \\
N=26-37\end{array}$ & $\begin{array}{c}\text { Supporting } \\
\text { materials } N= \\
26-37\end{array}$ & $\begin{array}{c}\text { Topic } \\
\text { coverage }\end{array}$ & $\begin{array}{c}\text { Under } \\
\text { Graduates } \\
N=24-37\end{array}$ & $\begin{array}{l}\text { Graduates } \\
N=26-37\end{array}$ \\
\hline Skolnik & 3.77 & 3.74 & 4.00 & 3.49 & 3.86 & 4.44 & 4.14 & 3.24 \\
\hline Markle & 3.68 & 3.86 & 3.59 & 3.49 & 3.81 & 4.24 & 3.38 & 3.76 \\
\hline Lindstrand & 3.02 & 3.24 & 3.21 & 3.14 & 2.50 & 3.19 & 3.07 & 3.10 \\
\hline Seear & 2.80 & 2.88 & 2.96 & 2.61 & 2.77 & 2.92 & 3.03 & 2.66 \\
\hline Jacobson & 2.64 & 2.83 & 2.96 & 2.62 & 2.13 & 2.92 & 2.96 & 2.46 \\
\hline
\end{tabular}

Scale: 5 , outstanding; 4 , very good; 3 , good; 2 , fair; 1 , poor.

Notes: $N=$ The number of individual scores for each parameter. Four measures: information, presentation, illustrations and supporting materials. Topic coverage: based on a composite of the data in Table 2 and a list of competencies described in the text. 
indicated that - in a pairwise comparison - ratings for both the Skolnik and Markle books differ significantly from each of the three other books, but they do not differ significantly from each other. Likewise, the three other books do not differ significantly from each other. These differences were very consistent with the majority of qualitative comments.

\section{Comparison by 12 subject categories and 18 competencies}

The content of the books could be conveniently divided into 12 subject categories shown in Table 2. Two books (Skolnik and Markle) covered 11 or 12 of these categories, while each of the other three covered eight subjects; however, omissions differed among these three books. For each book, each subject category was rated on four quality parameters (information, presentation, illustrations, and supplemental information) and the pooled data are shown in Table 2. However, this fine-grained analysis should be interpreted with caution, since each cell is based on only 6-20 responses. A scan of these cells indicates that the best-rated books had selected points of weakness while the books with lower ratings had individual points of strength.

An alternate approach to subject coverage was to use a list of 'competencies' in global health and determine what proportion of these competencies was represented in each book. A list of 18 competencies was compiled based on discussions by the GHEC Committee on Education. These are: (1) history of global health, (2) determinants of health, (3) health indicators, (4) health economics, (5) demography, (6) health systems, (7) culture and health, (8) environmental health, (9) occupational health, (10) human rights, (11) ethics, (12) maternal and child health, (13) vulnerable populations, (14) humanitarian disasters, (15) communicable diseases, (16) non-communicable diseases, (17) players in global health and (18) careers in global health. The five books ranged in their coverage of these topics from a high of $14 / 18$ to a low of $9 / 18$ topics. The Skolnik and Markle books received a higher rating on this scale compared to the other three books. We also computed a combined index of subject and competency coverage ('Topic coverage' in Table 3), which confirmed the relative hierarchy of books: Skolnik and Markle at the high end, Lindstrand intermediate, and Seear and Jacobsen at the low end.

\section{Comparison by student audiences}

When books were evaluated by potential student audiences (see Table 3), Skolnik stood out as a text for undergraduates while Markle received the best rating as a text for graduate and professional students.

\section{Overall ratings}

There are several salient findings. The Skolnik and Markle books were given the best ratings compared to the other three books (see Table 2), and this difference was statistically significant. An index of subject coverage was compiled (Table 2); again, the Skolnik and Markle books were leaders. The Skolnik text is a single author book that received the highest rating as an undergraduate text and was designed for that 
specific audience. The Markle text is a multi-author book that benefits from the expertise of individual experts but inevitably is less consistent than a single author book. It received the highest rating as a text for professional and graduate students. If one had to identify a 'best buy' among the two leading books, the Markle book at US $\$ 35$ would probably be selected by most reviewers.

Regarding the other three books, each of them has their own orientation and 'flavour'. They all deserve consideration. Depending on the student audience and course goals, each of them might be selected by individual teachers. Finally, these cumulative reviews provide input that authors might wish to consider in planning future editions of their books. Interested authors can obtain our raw data upon request.

\section{Acknowledgements}

Neal Nathanson led the study design, oversaw the data collection, performed the data analysis, and drafted the report. Thomas Hall participated in the study design, provided volunteers to participate in the study, contributed evaluation of the books, and revised the report. Neither author has a conflict of interest.

Abigail Cohen designed the Surveymonkey(C) questionnaire and abstracted the raw data, and Amy Praestgaard provided statistical consultation, both courtesy of the Center for Clinical Epidemiology and Biostatistics, Department of Epidemiology and Biostatistics, School of Medicine, University of Pennsylvania. Timothy Brewer, Committee on Education, and members of his committee, Global Health Education Consortium, provided advice and guidance in designing the study.

The following reviewers participated in the survey of individual chapters: faculty and experts - Andrea Boggio, Timothy Brewer, Connie Currier, Richard Deckelbaum, Edward Emmett, Suzinne Pak-Gorstein, Wayne Hale, Amy Lee, Graham Lister, Theresa Lynch, Sharon McDonnell, Nazanin Meshkat, Stephen Morris, Christopher Murray, Padmini Murthy, Thomas Novotny, Trevor Penning, Antonio Sarria-Santamera, Christopher Stewart, Anvar Velji and Calvin Wilson; students - Tonia Berg, Eileen Cheung, Alexa Coughlin, Jennifer Hulme, Sarah Hughes, Sirina Keesara, Farhad Modarai, Kim Mooney, Tej Nuthulaganti, Ian Pereira, Nitasha Puri, Trisha Rys and Beverly Wudel. We thank them for their invaluable assistance.

\section{Notes}

1. Books that were considered but not included in our study were: Birn, A.-E., Pillay, Y., and Holtz, T.H. Textbook of international health: Global health in a dynamic world. Oxford University Press, 2009; Drain, P.K., Huffman, S.A., Pirtle, S., and Chan, K. Caring for the world: A guidebook to global health opportunities. University of Toronto Press, 2009; Holtz, C. Global health care: Issues and policies. Jones and Bartlett Publishers, 2008; Johnson, J.A. and Stoskopf, C.H. Comparative health systems: Global perspectives for the 21st century. Jones and Bartlett Publishers, 2009; Levine, R. Case studies in global health: Millions saved. Jones and Bartlett Publishers, 2007; Merson, M., Black, R.E., and Mills, A.J. International public health. Jones and Bartlett Publishers, 2005; Murthy, P. and Smith, C.L. Women's global health and human rights. Jones and Bartlett Publishers, 2009; Perlman, D. and Roy, A. The practice of international health: A case-based orientation. Oxford University Press, 2008; Sharma, M. and Atri, A. Essentials of international health. Jones and Bartlett Publishers, 2009.

2. The full text of the qualitative comparisons of the books, along with additional supplementary information regarding our methodology and findings, can be found by accessing the link at the top of the online version of this review.

3. Jamison, D.T., et al. Disease control priorities in developing countries. Second edition. World Bank, Washington, DC, 2006. 